\title{
CONSIDERATIONS ON THE MORPHOLOGICAL CHANGES ON MOLDOVA RIVER LOWER COURSE AND THE EVOLUTION OF REGULARIZATION WORKS
}

\author{
Mihail Luca ${ }^{1}$, Paul Vivian Sion ${ }^{2}$, Mihaela Avram ${ }^{2}$, Ilie Logigan ${ }^{3}$, \\ Ştefania Chirica ${ }^{2}$
}

Keywords: erosion, flow, jetty, low weir, minor river bed

\begin{abstract}
The paper presents an analysis of the morphological changes created on the Moldova River lower course. The studies and researches were carried out on the sector around Pildeşti locality, where Roman water catchment is located. The successive floods from 1994 to 2018 have morphologically modified the Moldova River minor river bed, which determined supply parameters of the wells located on the left bank of the river. The minor river bed moves horizontally during floods due to the degradation of the jetties and the enclosure beams. The floods of 2016 and 2018 partially and totally destroyed some of the riverbed's shore protections. Also, part of the shore protection works have been degraded, which has influenced the stability of the Moldova River left bank. The floods in the past ten years have led to the displacement of the minor river bed towards the right river bank by breaking the old enclosure dikes and the jetties. Studies conducted during 2012-2018 analysed hydrological, hydraulic, morphological and topographic parameters on the considered river sector. The research analysed the concurrence of regulation and protection works in the water catchment area during floods. The flood of 2016 forced the restoration of the Moldova River minor river bed, to ensure the optimum wells operation.
\end{abstract}

\section{Introduction}

Significant climate changes have taken place over the last 30 years in Europe and, implicitly, in Romania. These have generated a negative impact on the environment. Climate change has influenced the annual distribution of precipitation and flow in river basins. The seasonal change of meteorological parameters creates

\footnotetext{
${ }^{1}$ Ph.D.eng. Professor, „Gh. Asachi” Technical University of Iasi, mluca2004@yahoo.com

${ }^{2} \mathrm{PhD}$ stud. "Gheorghe Asachi”'Technical University of Iasi, Romania, Doctoral School

${ }^{3} \mathrm{PhD}$ stud. "Gheorghe Asachi'”Technical University of Iasi, Romania, Doctoral School
} 
hydrological risk phenomena in local and regional areas in Romania (Avram, 2016). The development and evolution of the maximum flows on rivers was influenced, causing flood waves with disaster effects. Continuously changing hydrological parameters influence the morphological evolution of the river bed, but also the behaviour of river bed and riparian area constructions (Ichim et al., 1989).

The hydrological regime in the Moldova River hydrographic basin is characterised in the last period of time by the high floods frequency.

The floods that have occurred over the last years on the Moldova River have caused significant economic damage (ABA Siret, 2016). The Moldova River lower course is heavily influenced by the floods in the last 20 years. These changes influence the stability of river bed and riparian area objectives. Among these objectives are the bridges in Timişeşti, Tupilaţi, Roman; water catchment works located on the left bank of the river in Pildești area; water catchment in Cordun area, Neamţ County (Luca et al., 2016, Luca and Stoenescu, 2017).

The purpose of the paper is to present the results of studies and researches on the behaviour of Moldova River bed and the riparian area on the lower course. A particularisation of the researches was carried out in the area of Pildești locality, Neamţ County. In this area the water catchment of the Roman City is located, made of drilled wells on the river bank.

\section{Study area and research method}

The studies and researches were carried out on a Moldova River sector located between the villages of Pildeşti and Cordun (Neamţ County). The research area covered the river bed and the riparian area.

The research area consists of the minor and major river bed of Moldova River and the riparian area, where are located a number of objectives influenced by water action. Such an objective is the drinking water catchment of Roman City (ApaServ Roman, 2014). It is located on the Moldova River left bank, in Pildeşti area. The water catchment collects groundwater and the constructions are located in the riparian area. A detailed research has been carried out on the regulation works of Moldova River in the catchment area (jetties, enclosure beams and low weirs) and left and right shore protection works on the minor river bed. 


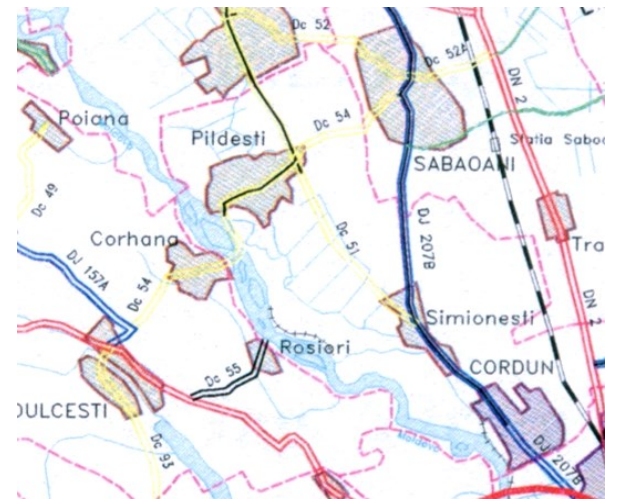

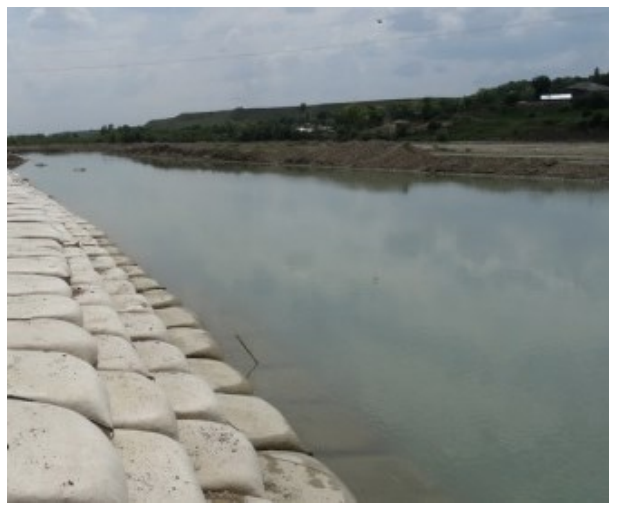

$\mathrm{b}$

Fig. 1. Location of the study area: $\mathrm{a}$ - administrative map; $\mathrm{b}$ - general view of the Moldova River in the drilling area, year 2018.

Theoretical and experimental research was conducted in the following fields:

1. Research of hydrological and hydraulic parameters (velocity, erosion velocity) on the study sector located on Moldova River.

2. Research of the morphological changes of the Moldova River bed and the influence of the regulation works on the wells location area.

3. Research on the behaviour in time of protection works on the left bank of the Moldova River on the wells location area.

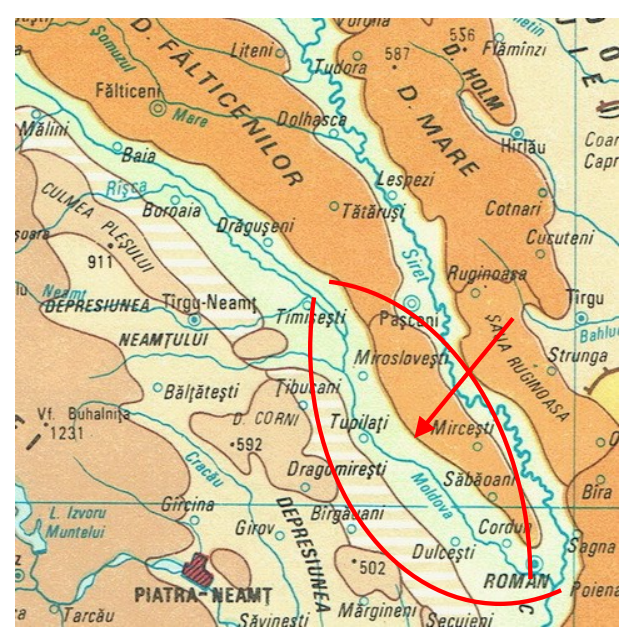

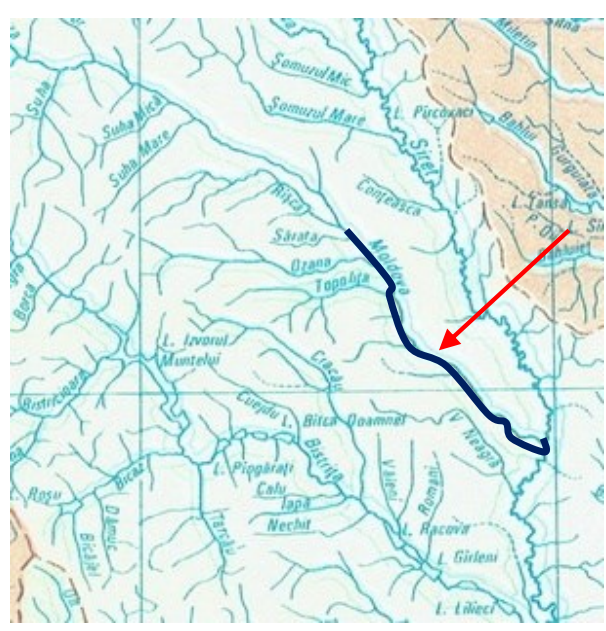

b

Fig. 2. Geophysical elements of the study area: a - physical map of the study area (Atlas geographic, 1985); b - analysed river basin area (Water Cadastre Atlas, 1992). 
Moldova River has in the research area a weakly meandered route with an NW - SE orientation.

The hydrological research analysed parameters of the maximum flow on the river section taking into account the values recorded at Tupilaţi Hydrometric Station, Neamț County.

The analysis of the structural and functional state of the existing works in the field was carried out by direct inspection, topographical measurements, visualisation of degradation forms, measurement of geometric parameters, photo and video recordings etc. The data taken from the field were compared to those in the technical documentation, or in similar works done internally and externally.

The data collected through documentation and fieldworks were processed using the statistical, hydrological and hydraulic computational programs applicable to the case study.

\section{Results and discussions}

A set of research was conducted on the Moldova River study section between 2014 and 2018. They analysed the behaviour of river regulation and shore protection works during floods. At the same time, the design process and behaviour of the materials used for the constructions were analysed.

The analysis considered hydrological parameters taken from the closest hydrometric station (Tupilaţi Hydrometric Station) and parameters calculated in the study section (Avram, 2016). The analysis of transit flows was performed over time periods of 10 years, 25 years and 55 years. The precipitation analysis showed that the maximum values were recorded in different periods of the year: May - 1972, June and July - 1969, July and August - 1991, September - 2001, April - 2005, July - 2008 etc. (Avram, 2016). The torrential precipitations are more present during the last 20 years on the Moldova River hydrographic basin territory.

Table 1. Multi-year average precipitation $\left(1 / \mathrm{m}^{2}\right)$ at Tupilaţi HS (ABA Siret, 2016)

\begin{tabular}{|c|c|c|c|c|c|c|c|}
\hline Month & I & II & III & IV & V & VI & VII \\
\hline $\mathrm{P}\left(l / \mathrm{m}^{2}\right)$ & 17.9 & 19.2 & 24.2 & 43.6 & 65.5 & 83.5 & 86.1 \\
\hline $\mathrm{M}$ & VIII & IX & X & XI & XII & Annual & \\
\hline $\mathrm{P}\left(l / \mathrm{m}^{2}\right)$ & 62.9 & 47.7 & 28.5 & 24.3 & 22.7 & 526.1 & \\
\hline
\end{tabular}

The change of the multi-year rhythm of rainfall it is useful to present these changes of rhythm pacehas generated high-speed flows in a very short time. (Tabel 1). This situation was recorded in 1992, 2005, 2006, 2008, 2010, 
2016 and 2018. The increase of the precipitation frequency, especially the torrential ones, with significant quantitative values, led to important floods on the Moldova River in the study area (Vamanu, Olariu, 2012).

The analysis of hydrological data has highlighted a high floods frequency over the last 20 years (Avram, 2016). Flows with high values have been prevalent over the last 15 years. Tupilaţi H.S. data processing showed that the maximum annual flow rate during 1990-2014 was $1402 \mathrm{~m}^{3} / \mathrm{s}$ (1991, July, calculation probability $\mathrm{p} \approx 3 \%$ ) (Fig. 3 ).

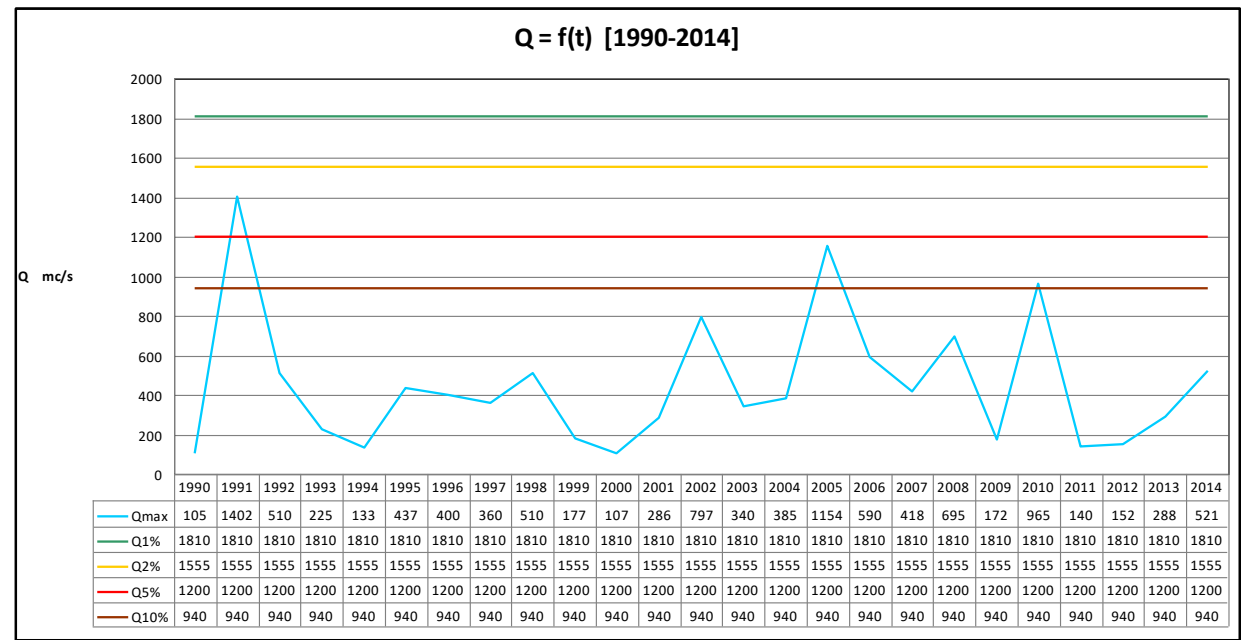

Fig. 3. The variation in the maximum annual discharges from 1990 - 2014 at H.S. Tupilati

The lowest peak flow rate was recorded in 1986 and $1990\left(105.0 \mathrm{~m}^{3} / \mathrm{s}\right)$. The minimum historical flow rate was $1.0 \mathrm{~m}^{3} / \mathrm{s}$ (1991, February) (ABA Siret, 2016). The hydrological studies for the design of regulation works drawn up in the study area (2016) indicated the calculation and verification flows but did not include the safety margin (Table 2). The average solids discharge in the Tupilati Station is $43.2 \mathrm{Kg} / \mathrm{s}$.

Table 2. Flows with calculation probability on the

Moldova River study sector (Aquaproiect, 2016)

\begin{tabular}{|c|c|c|c|c|c|c|}
\hline $\mathrm{p}(\%)$ & 2 & 5 & 10 & 20 & 50 & 95 \\
\hline $\mathrm{Q}_{\max }\left(\mathrm{m}^{3} / \mathrm{s}\right)$ & 1650 & 1275 & 1000 & 558 & 31.0 & 2.13 \\
\hline
\end{tabular}


Roman drinking water catchment is located in the riparian area of Moldova River near Pildeşti village, Cordun commune, Neamţ County. The catchment area is located on the Moldova River left bank and comprises 66 wells (code P1 - P66), drilled at depths of 7.50 - $14.0 \mathrm{~m}$. The wells have a diameter of $250 \mathrm{~mm}$, made of Dn $250 \mathrm{~mm}$ PVC tubes. The total average flow rate collected from the wells is $387.35 \mathrm{l} / \mathrm{s}$. The water volume adds to the water taken up by seven reinforced concrete coffers, which collects a total average flow $Q_{\text {totav }}=50.0 \mathrm{l} / \mathrm{s}$. The total catchment rate of Pildeşti (wells + coffers) is 437.35 1/s (ApaServ Neamţ, 2014, Aquaproiect, 2016).

The optimal functioning of the wells and coffers is conditioned by the existence of a minimum level in Moldova River bed. The sector, on which the catchment is located, has a river bed width of about $350-400 \mathrm{~m}$. The large river bed width has led to the appearance of meanders, morphological changes, and the displacement of the minor bed due to floods. To keep the minor river bed near the bank with water catchments constructions, regulation and shore protection works were designed and executed.

The shore regulation and protection works from the catchment area were executed starting from 1996. The works continued with interruptions during 2000-2006. The original shore regulation and protection works were made of the following (ApaServ Neamţ, 2014):

- regulation works: flow section calibration, minor river bed near the left bank profiling, flow routing through the use of a dike etc.; the dike was made of large stone set on fascine;

- shore protection works: reinforced concrete slabs placed on 1:1.5 slopes; the slabs rest on a simple concrete beam.

Part of the river bed regulation works degraded during 1996 - 2006. After 2006 some river bed and shore protection works were done by using geobags (geo-bags filled with local material, mainly ballast). Subsequent works in 2017 (jetties, enclosure dikes, shore protection) were executed only with geobags.

Hydrological changes over the last period of time have influenced the behaviour of regulation and shore protection works located in erodible riverbeds. The morphological change over time of the river bed causes new actions on the stability of hydrotechnical structures used as shore protection. The shore protection works are made of natural materials (wood, stone), artificial (plain and reinforced concrete, plastics) and composites. Shore protection works may be rigid (reinforced concrete, stone) and elastic (stone gabions, geo-bags) (Mitoiu, Marin 1999). Rigid shore protections do not behave efficiently in erodible beds (Luca et al., 2016, Ferguson, 2003).

Research conducted on the river sector has highlighted the following: 
- Under the floods action, the minor river bed is displaced from the left bank to the right bank, where the movement phenomenon is favoured by the geotechnical nature of the Moldova river bed foundation (variable thickness ballast). The minor river bed was artificially moved to the left bank by making a jetty and blocking the initial river bed with an enclosure dike (Fig. 4).

- Moldova River bed has a large width in the catchment area (about 250 $300 \mathrm{~m}$ ), which leads to important morphological changes in the transit of floods. The depth of water varies between 1.45 and $1.85 \mathrm{~m}$, with higher values after the low weir, at average flow rates. These changes should be illustrated by transverse profiles

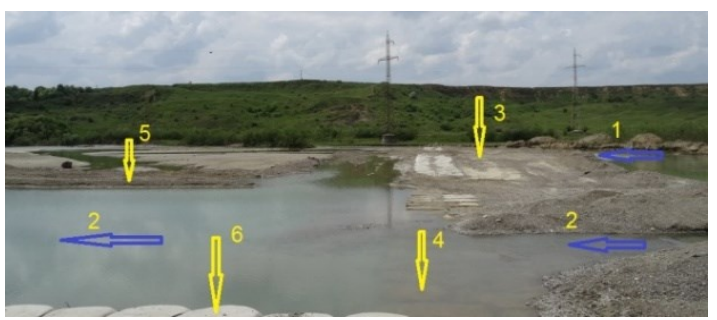

a

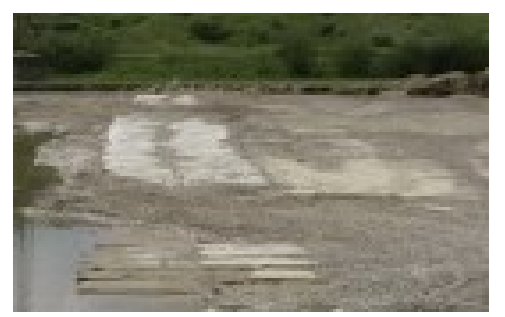

b

Fig. 4. Entrance section on the deviated river bank of Moldova River in the study area: a - general view of the deviated area; $b$ - detail on the enclosure dike; 1 - enclosed river bed, 2 - jetty, 3 - enclosure dike, 4 - deviated river bed, 5 - jetty and right bank of deviated river bed with shore protection, 6 - left shore protection (Photo Luca M., 2015

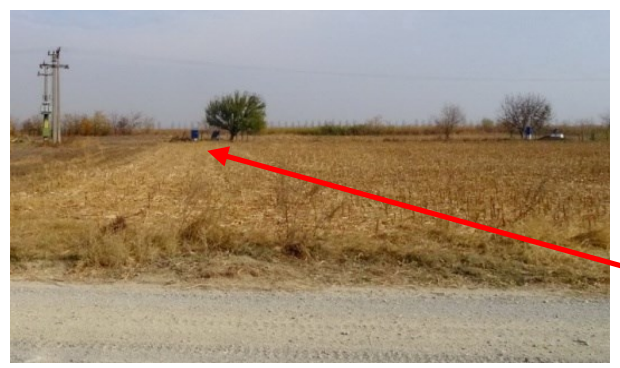

a

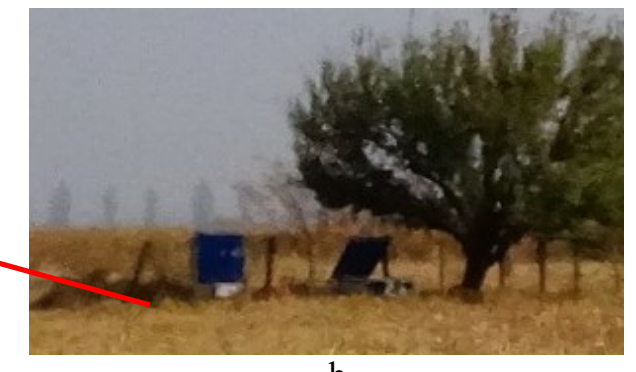

$\mathrm{b}$

Fig. 5. Catchment wells location area: a - overview of the site; $b$ - detail of the well construction.

- The floods from 2008 to 2012 produced important morphological changes in the configuration of the minor river bed. These are exemplified by the regular movement of the river bed towards the right bank due to the degradation of the enclosure dike to the old river bed (located towards the right 
bank). A first result of the change in the minor river bed position was the decrease of the flow to the river bed supplying the water catchment (Fig.5).

- The floods degraded the left shore protection consisting of old works (concrete slabs) and new works (ballast filled geo-bags) (Fig. 6). The shore protection made of concrete slabs is discontinuous in length, being degraded in proportion of $35-80 \%$. On some shore sectors it is completely degraded.

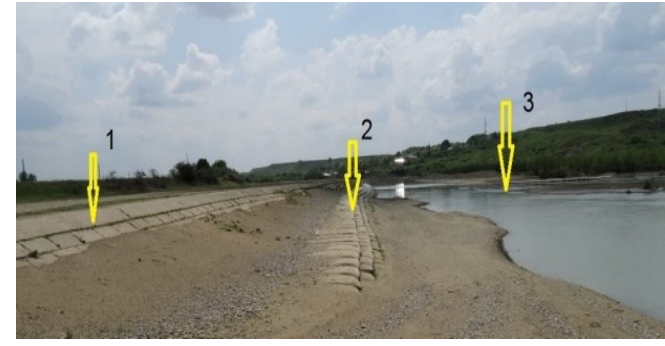

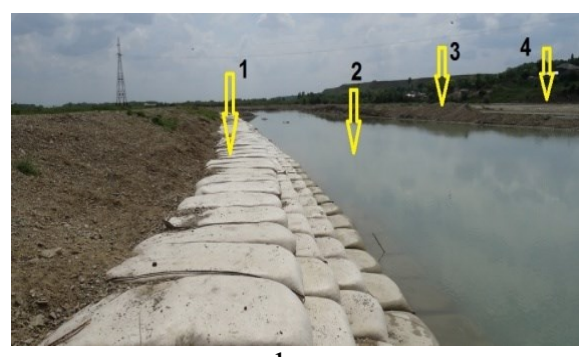

b

Fig. 6. General view left shore protection downstream of the deviation area: a - left bank with the presence of old and new left bank shore protection, 1- concrete slabs, 2-geo-bags, 3deviated bed; b - geo-bags shore protection, year 2015 (Photo Luca M., 2015).

- The low weirs were originally made of large stone (the side of at least $30 \mathrm{~cm}$ ) placed on a fascine mattress. After 2006, low weirs were made of geobags placed on fascination mattresses were executed (Fig. 7). The floods during 2006 - 2012 degraded the constructive structure at a number of low weirs by horizontally moving the geo-bags, breaking them, emptying the material etc. Floats in the minor river bed had an important role in the degradation process.

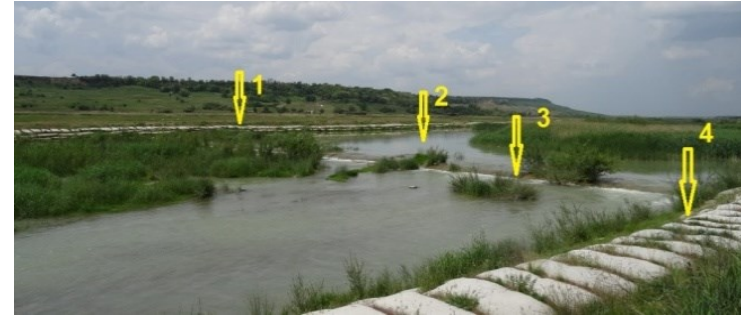

a

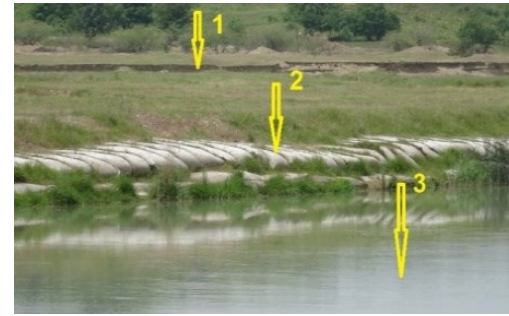

$\mathrm{b}$

Fig. 7. Geo-bags constructive components; a - general view of the river bed and low weir, 1 - right shore, 2 - deviated river bed, 3 - low weir, 4 - left shore; $b$ - detail on the right bank shore protection of the deviate riverbed, 1 - old river bed, 2 - geo-bags on the right bank, 3 deviated river bed, year 2015 (photo Luca M., 2015). 
- The flood of 2016 caused significant degradation in the structure of regulation and shore protection works. The old river bed enclosure dike was broken, which affected the well catchment flow rate (Fig. 8). This situation forced the urgent restoration of the enclosure dike.

- The 2016 flood imposed the redesign of some regulation works and their emergency construction in order to ensure the optimal operation of the groundwater catchment. The rehabilitation works applied in 2017 helped to restore the operational parameters of the low weirs and riverbed in drilling area (Fig. 9).

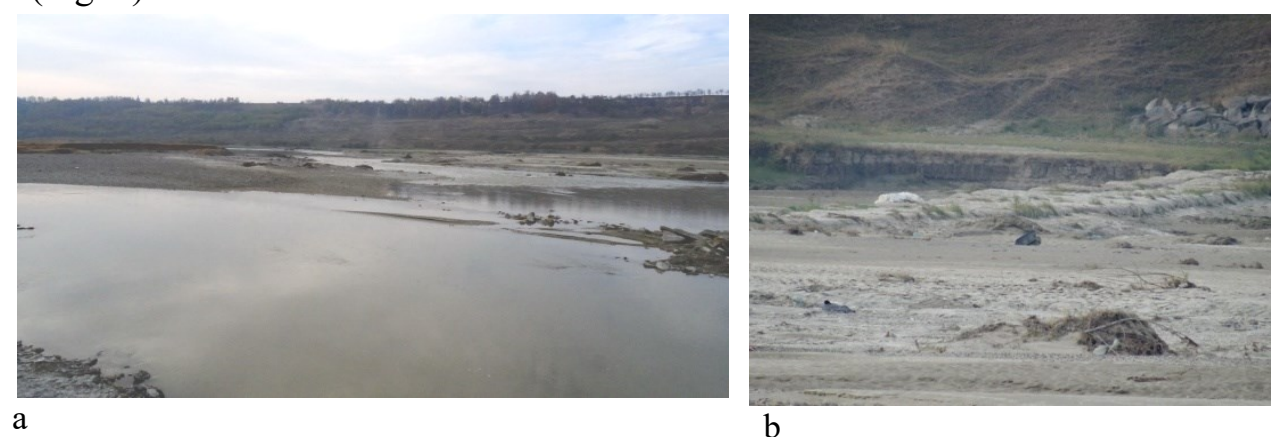

Fig. 8. Separation zone of the river beds in the catchment area: a - general view of the separation zone with the enclosure dike; $b$ - detail of the dike degradation, year 2018 (photo Luca M., 2015).

- The 2016 flood caused significant degradation in the structure of the shore protection made of geo-bags by breaking the geotextile and partially emptying the material. The rehabilitation works applied in 2017 contributed to the restoration of the low weir operational parameters (Fig. 10).

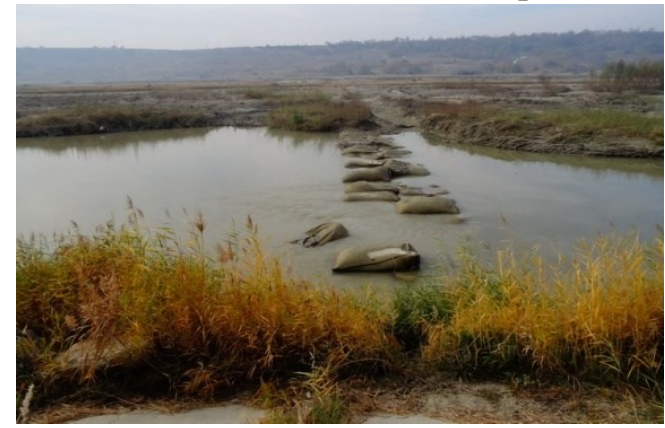

a

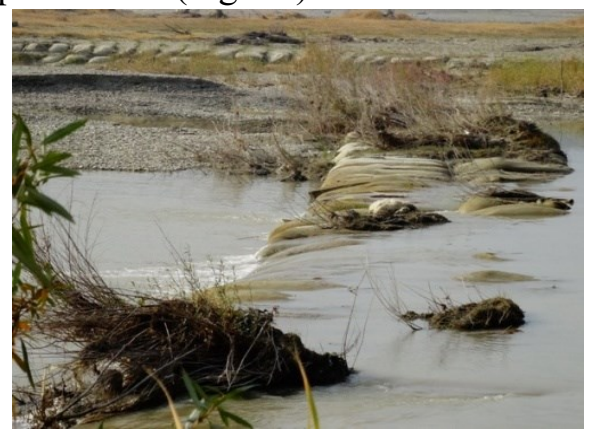

Fig. 9. Aspects regarding low weirs degradation on the deviated minor river bed, year 2018; a - general view; b - detail of the low weir (photo Luca M., 2018). 


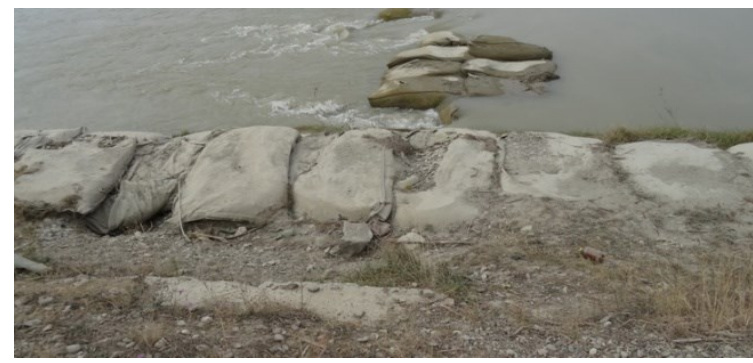

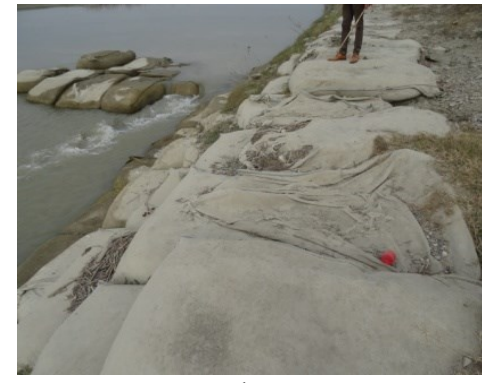

b

Fig. 10. Degradation of shore protection made of geo-bags on the deviated minor river bed, year 2018; a - elements degraded by floats in the water; b - degradation of geo-bags at the top of the shore protection (photo Luca M., 2018).

Elastic shore protections work efficiently with erodible river beds and do not affect the surrounding environment (Luca et al., 2016). The regulation and shore protection work in river beds made of poorly cohesive rocks must be calculated by taking into account the morphological changes formed in the vertical and horizontal plane as well as their evolution over time (Luca, Stoenescu, 2007, Shimizu, Italkura, Yamaguchi, 1989).

Transformation of the riverbed over 24 years (1994-2018) under the action of repeated floods and restoration of regularization work at short intervals of time shows the man's struggle with nature to master an area of the environment. Riverbed wants to return to the primordial position after every flood by destroying crushing works.

Geotechnical features of the site (the presence of poorly cohesive rocks at the base of the bed) contribute to the rapid degradation of the regularization works. Reduced investments in the implementation of efficient riverbed regulation works on the capture sector contribute to the emergence of morphological changes on the researched river sector.

\section{Conclusions}

The hydrological changes that occurred in the last 25 years on the Moldova River lower course in Pildeşti area caused the morphological modification of the cross-section and longitudinal profile, with the rapid degradation of the regulation works ensuring the stability of the studied river sector.

The high frequency of floods on the Moldova River lower course determined the degradation of the jetties and enclosure beams in the research 
area, which led to the periodic migration of the minor bed towards the right bank.

The high frequency of floods on the Moldova River lower course has led to the morphological modification of the minor river bed and the decrease of the optimal operational parameters of the shore wells potable water catchment located in the riparian area downstream of Pildești locality.

Repeated and high flows floods on the investigated river sector led to the rapid degradation of shore protection works made of reinforced concrete slabs.

\section{References:}

1. A.B.A. SIRET-Bacău Rapoartele de sinteză privind apărarea împotriva inundațiilor, fenomenelor hidrometeorologice periculoase, accidentelor la construcții hidrotehnice și poluărilor accidentale din județul Bacău, pentru anii 1991, 2004, 2005, 2010, 2016.

2. Avram M. (2016). Cercetări privind impactul factorilor de risc hidroclimatic asupra proiectării, tehnologiilor de realizare şi exploatării lucrărilor de regularizare a râurilor. Raport 2 de cercetare. Univ. Tehnică „Gheorghe Asachi” din Iaşi.

3. Ferguson R.I. (2003). Sudden onset transition-to-sand gravel along the river sorting processes, Geology, 312, 159-162 pp. 2003.

4. Ichim I., et al. (1989), Morfologia şi dinamica albiilor de râuri, Editura Tehnică Bucureşti.

5. Luca M., Stoenescu, I. (2007). Current Issues Concerning Regularization Works Behavior under Disaster Conditions. Intern. Conf. „Disaster and Pollution Monitoring - IC.DPM. 3". 1-2 nov. Iaşi, 93-98 pp.

6. Luca M., at al. (2016). Research on the stability of the defence works to eroded river beds. Ovidius University Annals, Series: Civil Engineering, Issue18, Ovidius University Press, p. 33-41.

7. Ministerul Mediului (1992). Atlasul cadastrului apelor din România.

8. Mitoiu C., Marin G. (1999), Regularizarea albiilor de râuri, Ed. BREN Bucuresti.

9. Romanescu G., Stoleriu C.C. (2013). Causes and Effects of the Catastrophic Flooding on the Siret River (Romania) in July-August 2008. Natural Hazards, 69:1351-1367. https://doi.org/10.1007/s11069-012-0525-6

10. S.C. Aquaproiect S.A. Bucureşti (2016) Refacerea amenajării râului Moldova în zona sursei de alimentare cu apă a oraşului Roman (frontul Pildeşti-Simioneşti), jud.Neamt.

11. Shimizu Y., Italkura T., Yamaguchi H., (1987). Calculation of two-dimensional flow and bed deformation in rivers. Proceedings of XXII ${ }^{\text {nd }}$ Congres of IAHR, Lausanne, pp. 2001-2015.

12. Vamanu E., Olariu P., (2002). Riscuri hidroclimatice în Spatiul hidrografic Siret in contextul modificărilor geografice. Culegere de lucrări, Sesiunea ştiinţifică anuală INMH Bucureşti. 
13. *** Atlasul geografic al României, (1985). Edit. Didactică şi Pedagogică, Bucureşti. 14. *** ApaServ S.A. Neamţ, (2014) Raport de activitate.

15. *** (1983), Geografia României, vol. I şi II, Ed. Academiei, Bucureşti.

16. $* * *$ http://www.rowater.ro/dasiret/default.aspx.

(C) 2020 by the authors. Licensee UAIC, Iasi, Romania. This article is an open access article distributed under the terms and conditions of the Creative Commons Attribution (CC BY-NC-ND) license (https:// creativecommons.org/licenses/by-nc-nd/4.0). 